МОНГОЛОВЕДЕНИЕ

(Монгол судлал)

(Mongolian Studies) (Elista)

Vol. 12, Is. 3, pp. 521-528, 2020

DOI: 10.22162/2500-1523-2020-3-521-528
ISSN 2500-1523 (Print)

ISSN 2712-8059 (Online)

Published since 2002

https://mongoloved.kigiran.com/jour

\title{
«Қазақ» гэх нэрийн дөрвөн хэлний дуудлагын тухай өгүулэх нь (= Произношение этнонима 'қазақ' в монгольском, казахском, китайском и русском языках)
}

\section{Нармандах Гомбын $^{1}$}

${ }^{1}$ Государственный университет г. Ланьчжоу (корп. 1, ул. Джиаюгуан, 730020

Ланьчжоу, Ганьсу, Китайская Народная Республика) аспирант

(iD) 0000-0002-6329-6203. E-mail: 1827079604@qq.com

\section{(C) КалмНЦ РАН, 2020}

(C) Нармандах Г., 2020

Аннотация. Введение. Казахи - тюркоязычный этнос, составляющий основное население современной Республики Казахстан. Проживают они также в смежных с Казахстаном районах Китая, России, Узбекистана, Монголии и в Турции. Казахи как этнос известны по древним письменным источникам под разными названиями, в том числе и по самоназванию ‘қ̧азақ̆'. Существуют несколько точек зрения на происхождение этого этнонима. По основной версии, он означает «свободный, вольный, независимый человек». Цель данной статьи - рассмотреть варианты произношения этнонима 'қ̧азақ,' на языках граничащих с Казахстаном стран - монгольском, китайском и русском. Результаты. Данный этноним имеет в монгольском языке два варианта произношения - 'хасаг' и 'казак'. Первый из них 'хасаг' представляет собой традиционную монгольскую форму произношения этнонима 'қазақ’, которым монголы с древних времен называли казахов. В монгольском языке все слова, начинающиеся на 'қ̧a' обретают форму ' $x a$ '. Вследствие этого тюркское 'қазақ, в монгольском языке обрело форму 'хасаг'. Второй вариант произношения 'казак' был заимствован монголами во второй половине $\mathrm{XX}$ в. из русского языка и является неологизмом. В китайском языке общепринятое произношение этнонима 'қ̧азақ' - 'hasake' аналогично тому, как китайцы произносят другие этнонимы: монгол - 'menggu', русский — 'eluosi', ойрат — 'weilate', 'elute'. В русском языке вплоть до начала ХХ в. казахов называли 'киргиз-кайсаками' или 'киргизами'. Затем было принято наименование 'казак', которое вскоре стали произносить и писать как 'казах'.

Ключевые слова: этноним, қазақ, монголы, хасаг, монгольский язык, русский язык, казак, казах

Благодарность. Материалы статьи апробированы на Международной научной онлайн-конференции «Монголоведение в начале XXI в.: современное состояние и перспективы развития-ІІ», проведенной при финансовой поддержке РФФИ (проект № 2009-22004) и частичной поддержке гранта Правительства РФ (№ 075-15-2019-1879). 
Для цитирования: Нармандах Г. «Қазақұ» гэх нэрийн дөрвөн хэлний дуудлагын тухай өгүүлэх нь (= Произношение этнонима 'қазақ' в монгольском, казахском, китайском и русском языках) // Монголоведение. 2020. Т. 12. № 3. С. 521-528. (На монг.). DOI: $10.22162 / 2500-1523-2020-3-521-528$

UDC 821.512 .37

DOI: $10.22162 / 2500-1523-2020-3-521-528$

\title{
The Ethnonym Kazakh in Four Languages (Mongolian, Kazakh, Chinese and Russian): Spelling Variants Revisited
}

\author{
Narmandakh Gombyn ${ }^{1}$ \\ Postgraduate Student \\ iD 0000-0002-6329-6203. E-mail: 1827079604@qq.com \\ (C) KalmSC RAS, 2020 \\ (C) Narmandakh G., 2020
}

${ }^{1}$ Lanzhou University (1, Chengguan, Lanzhou 730030, Gansu, People's Republic of China)

\begin{abstract}
Introduction. Kazakhs are a Turkic people dominant in present-day Republic of Kazakhstan. The former also reside in adjacent territories of China, Russia, Uzbekistan, Mongolia, and Turkey. Ancient written sources employed quite a number of ethnonyms including the endonym қ̧азақ (Qazaq) — to denote the ethnos. And the issue of etymology is still debatable. According to the main version, the word қазақ stands for a 'free, unrestricted, independent person'. Goals. The paper seeks to examine spelling variants of the ethnonym in national languages of bordering countries - Mongolian, Chinese, and Russian. Results. The ethnonym has two spelling variants in Mongolian, namely: хасаг and казак. The former is the traditional spelling adopted by Mongols since ancient times. In Mongolian, the first syllable $\kappa a-(k a-)$ turns into $x a-(k h a-)$, which thus gave rise to the mentioned form. The second spelling variant was borrowed in the mid-to-late $20^{\text {th }}$ century from Russian, and is a neologism. The Chinese hasake is as transformed as other ethnonyms, e.g., монгол (Mongol) - menggu, русский (Russian) - eluosi, oüрат (Oirat) - weilate, elute. Russians tended to call Kazakhs 'Kirghiz-Kaisaks', or 'Kirghizes' till the early $20^{\text {th }}$ century. The latter ethnonym was replaced by қ̧азақ (Qazaq), and further the spelling казаx (Kazakh) was officially accepted.
\end{abstract}

Keywords: ethnonym, Qazaq, Mongols, Khasag, Mongolian language, Russian language, Kazak, Kazakh

Acknowledgements: The article was presented at the international scientific online conference "Mongolian Studies at the beginning of the 21st century: Current State and Development Prospects - II”, held with the financial support of RFBR (project № 20-0922004) and partial support of the Russian Government Grant (№ 075-15-2019-1879).

For citation: Narmandakh G. The Ethnonym Kazakh in Four Languages (Mongolian, Kazakh, Chinese and Russian): Spelling Variants Revisited. Mongolian Studies (Elista). 2020. Vol. 12. No. 3. Pp. 521-528. (In Mong.). DOI: 10.22162/2500-1523-2020-3-521528 


\section{Оршил}

Хасаг нь олон улс дамнасан үндэстэн юм. Ихэнх нь Казахстан, Узбекстан, БНХАУ-д оршин суудгаас гадна Монгол, Орос, Турк гэх мэт улсуудад мөн нэлээд тоогоор байдаг. Дэлхий даяар тархсан хасаг үндэстний хүн амын тоо 15 сая хүрч байгаагаас 12,09 сая нь Казахстанд [Казахстаны хасаг 2018], 1,46 сая нь БНХАУ-д [Хасаг үндэстний 2019], 2 сая нь Узбекстанд, 1 сая нь ОХУ-д, 146 мянга орчим нь Монгол Улсад оршин сууж байна [Алтангүл 2017: 6]. БНХАУ-ын хасагуудын ихэнх нь ШУӨЗО-ны хойт хагас Илийн хасаг үндэстний өөртөө засах аймаг (область), Тарвагатай болон Алтайн газар орон (район)-д төвлөрөн суудаг (Шинжааны Бархөл болон Ганьсугийн Ахсай, Хөхнуурын Махай зэрэг газар бас цөөн боловч бий) бөгөөд энэ нутаг нь Монгол Улсын баруун хязгаар болох Баян-Өлгий, Ховд аймагтай хил залгадаг. Харин Баян-Өлгий аймаг нь Монгол Улсын хасаг үндэстний төвлөрөн суудаг нутаг билээ.

Өөрөөр хэлбэл, БНХАУ-ын хасагууд ба Монгол Улсын хасагууд хоорондоо хоёр улсын хилийн зурвасаар зааглагдаж байгаа гэсэн үг юм. Энэ нь газарзүйн байрлалын хувьд Алтай нурууны зүүн хойд, зүүн, зүүн өмнөд хэсэг болно. Хасаг үндэстэн нь мал аж ахуй эрхлэдэг нүүдэлчин үндэстэн тул Кипчакийн тал, Алтайн нуруу, Тэнгэр уулын газарт мал маллан амьдарсаар байна. БНХАУ-ын хасаг үндэстний хувьд хасаг, хятад хоёр хэлтэй бөгөөд эх хэлээ хасаг хэлэнд тохируулан зохиосон араб үсгээр тэмдэглэдэг. Монгол Улсын хасагууд харин хасаг, монгол хоёр хэлтэй бөгөөд Казахстантай адилхан хасагийн кирилл үсэг хэрэглэдэг. Тиймээс энэ хоёр улсын хасаг үндэстэн эх хэлээрээ харилцан нэвтрэлцэж болох авч бичгээр ойлголцоход бэрх юм.

\section{Хасаг гэх нэрийн тухай}

'Хасаг' гэх нэрийн түүхийн тавцанд анх гарч ирсэн хугацаа, нэрийн утга учир зэргийн талаар олон янзын тайларбар байдаг. Тиймд одоог хүртэл нэг санал, дүгнэлтэнд хүрээгүй гэж ойлгож болно. Тэдгээр саналаас гурван хувилбар нь судлаачдын анхааралыг илүү татдаг.

Нэгдүгээрт, цагаан хун шувуунаас гаралтай. Хасаг гэдэг нь 'ияадан хун' гэсэн утгатай [Патиман 2008: 6]. Хоёрдугаарт, хасаг гэх нэр нь 'хасаг тэрэг'-тэй холбоотой. «Тэд хасаг тэрэг хөллөн нутаг сэлгэн нүүж, хэнд ч захирагдалгүй эрх чөлөөтэй амьдардаг тул ийм нэртэй болжээ» [Жианьшинь 2012: 553]. Гуравдугаарт, хасаг гэдэг нэр нь монгол хэлний 'хасах’ гэдэг үгтэй холбоотой. «Чингис хааны бага хүү гэмт хэрэг үйлдэж монголоос хөөгдөөд, тэр нь хожмоо хасаг үндэстний дээдэс болсон» гэж домоглодог [Монголын казахын 2016: 9].

Ийм гурван хувилбараас гадна 'касa', 'хасa', 'косак', 'кас-сах' гэх мэт нэрүүдээс үүссэн гэж бас үздэг. ЭнэхүҮ өгүүллийн маань гол зорилго нь ' $х a c a z '$ нэрийн үүсэл гарал, утга учирыг тайлбарлах биш тул энэ хүртэл товчхон өгүҮлэе.

\section{Хacaz гэх нэрийн дуудлагыг тайлбарлах нь}

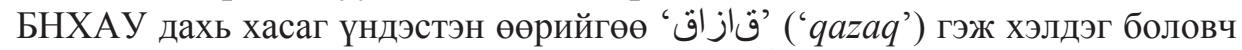
төрийн албан ёсны хэлэнд хятад үсгээр ‘哈萨克' гэж бичээд 'hasake' гэж дуудна [Хятад үсгийн толь 2015: 293]. Улс даяар улс төр, эрдэм шинжилгээ, эгэл ардын хүрээнд бүгд энэхүҮ нэрийг хэрэглэдэг. Өөр ямар нэг хувилбар 
байхгүй. Бусад цөөхөн тоот үндэстнүүд ч ерөнхийдөө энэхүҮ хэллэгийг баримжаа болгож хасаг үндэстнийг нэрлэдэг. Иймд тухайн үндэстний нэрийг зөв, буруу хэллээ гэх ямар нэг маргаан гардаггүй сайн талтай.

Монгол Улсын хувьд хасаг бол цорын ганц үндэсний цөөнхөд тооцогддог бөгөөд тэд өөрсдийгөө мөн 'қазақ’ (qazaq) гэж хэлдэг нь БНХАУ-ЫН хасагуудтай адил юм. Гэвч, Монгол Улсын монгол хэлэнд хасаг үндэстний нэрийг 'казах' (kazakh) гэж бичээд 'казак' (kazak) гэж дууддаг. Мөн 'хасаг' (hasag) [Монгол-казах толь 2015: 164] гэсэн бас нэг хувилбар байдаг нь тухайн нэрийн хэрэглээг нэгдэлтэй биш болгож, зарим тохиолдолд их, бага үл ойлголцлыг дагуулдаг. Одоо цагт, ялангуяа 1990 онд ардчилсан Монгол Улс байгуулагдсан цагаас хойш 'хасаг' гэдэг үгийг сонссон хасаг хүн төдийлөн дуртай биш, сэтгэл дундуур байгаагаа илэрхийлдэг. Энэ нь, нэгдүгээрт, 'хасаг' гэдэг нэрэнд ямар нэгэн хасаг үндэстнийг дорд үзсэн, гадуурхсан утга агуулагдаж байна гэж үздэгтэй холбоотой. Хоёрдугаарт, дээрх шалтгаанаас болоод 'казах' гэх нэрийг хэрэглэхийг илүүд үздэг билээ.

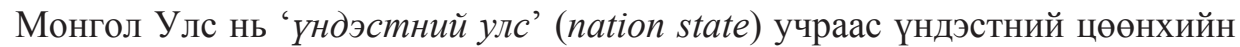
талаарх бодлого БНХАУ-тай харьцуулбал хангалттай биш байдаг тул зарим талаар БНХАУ-ын үндэстний цөөнхдөө авч хэрэгжүүлж буй бодлогоос туршлага хуваалцах хэрэгтэй мэт санагддаг. Тиймээс миний бие энэхүу өгүүллээр дамжуулан 'хасаг’ болон 'казах’ гэх хэллэгт тайлбар хийж, өөрийн саналыг дурдахыг зорьж байна.

Хасаг хэлэнд ‘хасад’ гэдэг үгийг قاز / ‘қaзaқ̧’ (qazaq) гэж хэлдэг. Монгол хэлэнд اق / 'ķa' гэдэг авиа байхгүй. Өөрөөр хэлбэл монгол хэлэнд ' $k a$ ', ‘ $k e$ ’, ‘ $k i$ ', ' $k o$ ', ‘ $k u$ ', ‘ $k ø ’$, ' $k \ddot{u}$ ’ авиагаар эхэлсэн үг огт байхгүй. Хэрэв ' $k$ ’ авиагаар эхэлсэн үг тааралдвал тэр нь лав гадаад үг буюу зээлмэл үг болж таарна. Хэрэв сонсоход ‘ $\kappa$ ' авиагаар эхэлсэн үг хэлж байвал тэр нь нэг бол зээлмэл буюу гадаад үг, нэг бол нутгийн аялгуугаар хэлж буй үг юм. Монгол хэл олон нутгийн аялгуутай байдаг тул зарим нутгийн аялгуунд (ойрад, ордос, алашаа, зарим халх нутаг)

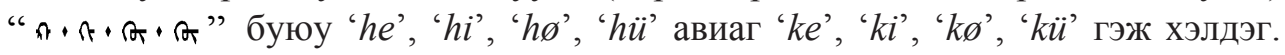

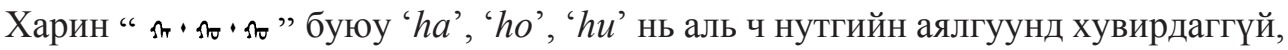
тэр янзаар нь хэлэхээс биш ' $k a$ ', ' $k o$ ', ' $k u$ ' гэж хэлдэггүй. Хэрэв ' $k a$ ', ' $k o$ ', ' $k u$ 'aар эхэлж хэлж байвал тэр нь маргаангүй зээлмэл үг эсвэл гадаад үг болж таарна.

Монгол, хасаг хоёулаа алтай язгуурын хэлт үндэстэн учир ойролцоо дуудлагатай, адил утгатай үг маш олон байдаг. Мөн түүхийн аль нэг үед харилцан нөлөөлсөн зүйл ч бас байх нь магад. Хасаг хэлний үгийг монгол хэлний авиа, дуудлагын онцлогт тохируулан монголчлон дуудаж бүрэн болдог.

Жишээлбэл:

\begin{tabular}{|c|c|c|c|c|c|}
\hline \multicolumn{2}{|c|}{ Хасаг хэлний үг } & \multirow[b]{2}{*}{ Дуудлага } & \multirow{2}{*}{$\begin{array}{c}\text { Монгол хэлний } \\
\text { үг }\end{array}$} & \multirow[b]{2}{*}{ Дуудлага } & \multirow{2}{*}{$\begin{array}{c}\text { Хятад } \\
\text { орчуулга }\end{array}$} \\
\hline $\begin{array}{c}\text { Араб } \\
\text { үсгээр }\end{array}$ & $\begin{array}{c}\text { Кирилл } \\
\text { үсгээр }\end{array}$ & & & & \\
\hline رىيا & айыр & ajər & hग्यार & ajr & 叉子 \\
\hline اراق & қара & qara & sint? & qar-a & 黑 \\
\hline نىتل| & алтын & altən & ריף & altan & 黄金 \\
\hline
\end{tabular}




\begin{tabular}{|c|c|c|c|c|c|}
\hline قُس & cy & sw & 1िभि & vsv (usu) & 水 \\
\hline لرام & мал & mal & 仵 & mal & 牲畜 \\
\hline يوق & қой & qoj & stor & qoni & 绵羊 \\
\hline كـروُج & жүрек & dzürek & Txणn & dzirüqe (jirüike) & 心脏 \\
\hline ن نَر مهم & мерген & mergen & intint & mergen & 神枪手 \\
\hline كىره & ерік & erik & מרוזי & erqe (erke) & 自主权 \\
\hline 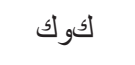 & көк & $\mathrm{k} ø \mathrm{k}$ & Oons & qøqe (köke) & 青 \\
\hline سىگت & тегіс & tegis & omrn & $\operatorname{teg} \int \mathrm{i}$ & 平面 \\
\hline ال الد & дала & dala & כודים & $\begin{array}{c}\text { qeger-e (keger-e) } \\
\text { tal-a } \\
\end{array}$ & 野外 \\
\hline ل كوكوك & көкег & køkeg & Ororn & qøqøge (kököge) & 布谷鸟 \\
\hline
\end{tabular}

[Хасаг-хятад толь 2017; Журамласан толь 2018]

Тиймээс хасаг хэлний 'қ̧a' авиаг монгол хэлний ' $x a$ ' авиагаар сэлгэж хэлдэг билээ. Уйгар хэлний 'қ̧a' авиаг ч мөн монгол хэлэнд ' $x a$ '-гаар хэлдэгийг Шинжааны монголчуудын ярианаас анзаарч болно. Тэд хасаг, киргиз, уйгар гэх мэт хэлнүүдийн 'қ̧a' авиаг ' $x a$ '-гаар хэлдэг. Жишээ нь: (راقشاق / Қашқ̧ар,

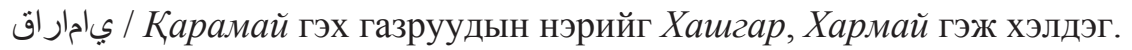

'Казах' гэдэг нэрийг Монгол Улсын монгол хэлэнд ЗХУ-аас авч хэрэглэсэн гэж хэлж болно. Учир нь, Монгол Улс (Тухайн үеийн БНМАУ) байгуулагдсан цаг (1921)-аaс ЗХУ-ын тал бүрийн дэмжлэгийг тасралтгүй авч, үргэлж харилцаж байснаас Монгол Улсын дотоод дахь улс төр, нийгэм, эдийн засаг, шинжлэх ухааны олон нэр томъёо, үг хэллэг орос хэлнээс монгол хэлэнд шууд орж ирсэн байдаг. Тэдгээр үгнүүдийн зарим нь шууд, зарим нь монгол хэлний дуудлагад тохирон хувирч хэрэглэгдэж ирсэн юм.

\section{Орос хэлнээс зээлж хэрэглэсэн үгийн жишээ}

[Pronunciation of words borrowed from the Russian language]

\begin{tabular}{|c|c|c|c|}
\hline Орос үг & Монгол хэлэнд & Дуудлага & Хятад орчуулга \\
\hline Техника & Тээхниг & Teehnig & 设备 \\
\hline Ботинок & Бажинк & Bajink & 皮鞋 \\
\hline Доктор & Доктор & Doktor & 医生, 博士 \\
\hline Чернила & Чирнэл & Chirnel & 墨水 \\
\hline Менеджер & Менежер & Menejer & 经理 \\
\hline Компьютер & Компьютер & Kompyuter & 电脑 \\
\hline Танец & Танц & Tants & 舞 \\
\hline Радио & Радио & Radio & 收音机, 广播电台 \\
\hline Радиатор & Аржаатар & Arjaatar & 暖气片 \\
\hline Социализм & Соцлизм & Sotslizm & 社会主义 \\
\hline Марка & Марк & Mark & 邮票 \\
\hline Редактор & Редактор & Erdaktor & 编辑 \\
\hline
\end{tabular}

[Их тайлбар толь 2016] 
Тиймд ‘казах’ гэдэг нэр ч адил орос хэлнээс монгол хэлэнд шууд орж ирж хэрэглэгдэх болсон.

1926 онд ЗХУ албан ёсоор ‘казах’ гэдэг үгийг хэрэглэх болсноор [Монголын казахын 2016: 10] Монгол Улсад ч гэсэн нөлөөлж, 'казах’ гэдэг үгийг хэрэглэх болсон. ЗХУ-д хэрэглэгдэж эхэлсэн энэ ‘казах' гэдэг нэр нь ЗСБНКУ болон тэр улсын хасаг иргэдийг нэрлэн заах утгатай. ЗХУ яагаад 'казак’ биш, заавал ‘казах' гэдэг нэрийг авч хэрэглэсэн нь бас учиртай.

Орос хэлэнд ‘казак' гэдэг нэр ‘казах’ гэдэг үг бий болохоос өмнө буюу хаант оросын үед хэрэглэгдэж байсан юм. Тэр үед хаант оросын төлөө зүтгэдэг морьт цэргийг ‘казак’ гэж нэрлэдэг байсан. Харин хасаг үндэстэн хүмүүсийг тэдгээр казакуудаас ялгахын тулд 'киргиз', ‘киргиз-казак', ‘киргиз-кайсак' гэх мэтээр нэрлэдэг байжээ. Энэ тухай оросын эрдэмтэн Г. Н. Потанины «Монголын баруун хойд нутагт» гэх номоос тодорхой харж болно [Потанин 2018]. ИйнхүY явсаар ЗХУ-ын үе болоход ЗХУ-ын засгийн газраас хасаг үндэстэн иргэдийнхээ жинхэнэ нэрийг хүндэтгэн үзэж 1926 оноос 'казах' гэдэг нэрийг албан ёсоор хэрэглэж эхэлсэн байна [Монголын казахын 2016: 10].

Гэхдээ ЗХУ-д хэрэглэж эхэлсэн энэхүу 'казах' гэдэг нэрээр бусад улсад оршин амьдарч байгаа хасаг үндэстнийг бас нэрлэх ёстой гэсэн үг биш юм. Учир нь аливаа улс, үндэстэн өөрийн хэл, бичгийн онцлогт тохируулан өөр нэг улс, үндэстнийг нэрлэж ирсэн уламжлалтай байдаг.

Жишээлбэл: хятад хэлэнд, монголыг 蒙古 (menggu), оросыг 俄罗斯 (eluosi), ойрадыг 瓦剌 (wala)、卫拉特 (weilate)、厄鲁特 (elute), зүрчинийг 女 真 (nvzhen), хасагийг 哈萨克 (hasake), төвдийг 西藏 (xizang), 藏族 (zangzu), солонгосыг 韩国 (hanguo), 朝鲜 (chaoxian) гэх мэтээр нэрлэж ирсэн байдаг [Хятад үсгийн толь 2015].

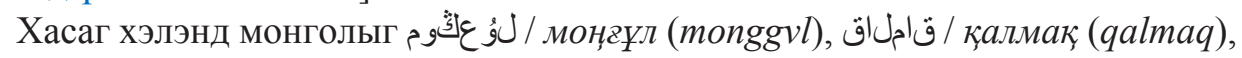

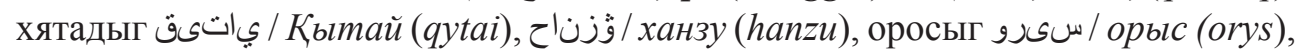
солонгосыг ايثروك / корей (korei) гэх мэтээр нэрлэж ирсэн байдаг [Хасаг-Хятад толь 2017].

Қалмақ (qalmaq) / قاحلاق гэх үг нь хасаг, уйгар, киргиз хэлэнд монголыг зааж хэлдэг үг бөгөөд 'үлдэгсэд’, 'үлдсэн' гэсэн утгатай үг юм. Хальмаг, Сарт хальмаг гэдэг үг ч энэХүҮ үгээс гаралтай билээ.

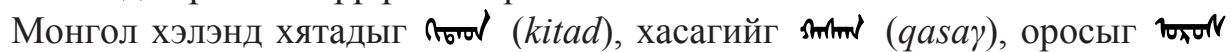

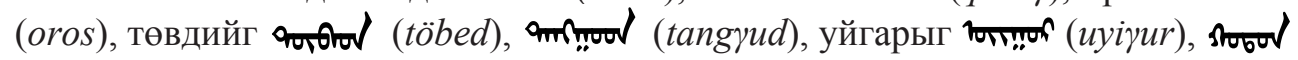
(qoton), soofl (chingduu / chantuu) гэх мэтээр нэрлэж ирсэн байдаг.

Энэ нь ихэнхдээ тухайн үндэстэн өөрийн хэлээрээ өөрийгөө хэрхэн нэрлэдэгээс үл хамааран эргэн тойрны бусад үндэстнүҮд тэднийг нэрлэж тогтсон уламжлал билээ.

Монголчуудын хувьд хасагтай хамгийн ойр, үргэлж харилцаж байсан нь ойрад монголчууд юм. Учир нь газарзүйн байрлалын хувьд монголчуудын хамгийн баруун хязгаарт, хасагийн нутгийн зүүн хилд хаяа залган суудаг нь ойрад монголчууд байсаар ирсэн. Ойрад монголчууд өөрсдийнхөө баруунд талд нь байх хөрш зэргэлдээ оршиж, үргэлж ямар нэг байдлаар харилцаж байдаг, аж ахуй, амьдралын хэм маягийн хувьд ойролцоо боловч хэлний

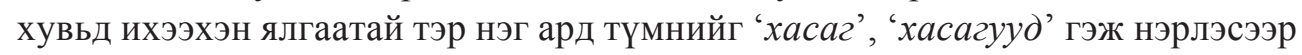
иржээ. 
Харин бусад газрын монголчууд ойрадуудаар дамжин хасагуудын талаар мэдээлэл авч, хэрэгцээ гарвал харилцдаг байсан болов уу. Тиймээс, ойрад монголчуудаас бусад нутгийн монголчуудын хувьд хасаг гэдэг нэр төдийлөн танил дасал биш байсан юм. Ялангуяа одоогийн Өвөр монголын ихэнхи монголчуудын хувьд бүр ч хол хөндий байсан биз. Тиймдээ ч тэд хасаг үндэстнийг нэрлэхдээ шууд хятад хэлний бичлэг, дуудлагаар дамжин ' $х a c a \kappa$ ' (qasak) гэдэг болсон болов уу. Харин халх монголчуудын хувьд 1912 оноос хасагуудын нэг хэсэгтэй улс төрийн шууд харилцаанд орж [Монголын казахын 2016: 26] эхэлсэн цагаас хойш хасаг үндэстэн, хасаг гэх нэртэй илүҮ ойртон танилцаж улмаар танил дасал болж эхэлсэн.

Тэр үед мөн л 'хасаг' гэх нэрийг хэрэглэж байгаад хожим нь ЗХУ-ын нөлөөгөөр 'казах' гэдэг нэрийг хэрэглэж, Монгол Улсад суурьшсан хасаг иргэдийн нэрийг 'казах’ гэж бичээд 'казак’ гэж хэлдэг болсоор өдийг хүрчээ. Гэвч хасаг үндэстнийг, 'хасад’ гэх нэрийг яг ингэж хэлж, тэгж бичнэ гэж албан ёсоор тогтоосон зүйл байхгүй. Зөвхөн 'казах' гэж хэлээд дасчихсан учраас өдгөө ихэнхдээ ‘казах' гэж бичээд 'казак' гэж хэлдэг.

Хорьдугаар зууны монголын эрдэмтэд ч 'хасаट’ гэдэг нэрийг хэрэглэдэг байсныг тэдний зохиол, бүтээлүүдээс үзэж болно. Жишээлбэл, Ж. Цэвээний бүтээлд 'хасаг' нэрийг хэрэглэсэн байдаг.

Одоо ч 'хасаг' гэж нэрлэдэг хүмүүс бас байсаар. Тэдгээр хүмүүс мөн л монголын хасагуудтай хаяа залган, эсвэл холилдон суудаг ойрад монголчууд болон баруун нутгийн халхчууд байдаг. Энэ нь зөвхөн хуучин уламжлалаа л дагаж буй хэрэг юм.

\section{Дүгнэлт}

ЭнэхүҮ өгүүллээр дамжуулан ‘хасаг’ гэдэг үгийн дуудлагыг тайлбарлахын хамт монголчууд 'хасад’ гэдэг нэрийг түүхийг урт удаан хугацааны туршид хэрэглэсээр ирсэн, ямар нэг буруу муу утга агуулаагүй гэдгийг харж болно. Мөн тухайн үндэстний нэрийн үүсэл гарал, тухайн үгийн утга агуулга ямар байхаас үл хамааран монгол үндэстэн өөрийнхөө хэлний онцлогт тохируулан нөгөө үндэстнээ дуудаж, нэрлэж заншсан үндэстний нэр төдий зүйл юм гэдгийг ойлгож болно.

\section{Ном зүй}

Алтангүл 2017 - Алтангүл Б. Казахын соёл, зан заншил (= Культура и традиции казахов). Улаанбаатар: Соёмбо принтинг, 2017. 108 х.

Жианьшинь 2012 - Жианьшинь Ян. БНХАУ-ын баруун хойтын цөөхөн тоот үндэстний түүх (= История национальных меньшинств северо-западной части КНР). Бээжин: Үндэстний хэвлэлийн хороо (= Национальное изд-во), 2012. 648 х.

Монголын казахын 2016 - Монголын казахын угсаатны зүй (= Этнография монгольских казахов) / ред. Г. Золбаяр. Улаанбаатар: Соёмбо принтинг, 2016. 288 х.

Патиман 2008 - Патиман. Хасаг үндэстний зан үйл ба соёл (= Культура и традиции казахов). Бээжин: Үндэстний хэвлэлийн хороо (= Национальное изд-во), 2008. $376 \mathrm{x}$.

Потанин 2018 - Потанин Г. Н. Монголын баруун хойд нутаг (= Очерки СевероЗападной Монголии). ІІ боть. Улаанбаатар: Судар Өргөө паблишинг, 2018. 304 х.

Их тайлбар толь 2016 - Монгол хэлний их тайлбар толь. ШУА-ийн Хэл зохиолын хүрээлэн эрхлэн гаргав (= Большой толковый словарь монгольского языка) / 
под ред. Ин-та языка и литературы АН Монголии. 3 боть. Улаанбаатар: Woovoo технологийн ХХК, 2016.

Монгол-казах толь 2015 - Монгол-казах толь (= Монгольско-казахский словарь) / ред. 3. Күлмесхан. Өлгий: Баспагер-Өлгий ХХК, 2015. 891 х.

Журамласан толь 2018 - Монгол хэлний зөв бичих дүрмийн журамласан толь (= Opфографический словарь монгольского языка) / ред. Ц. Өнөрбаян. Улаанбаатар: Соёмбо принтинг, 2018. 542 с.

Хасаг-хятад толь 2017 - Хасаг-хятад толь (= Казахско-китайский словарь) / ред. Хэ Яньлун. Бээжин: Бээжингийн Лу яо технологи ХХК, 2017.

Хасаг-англи толь 2017 - Хасаг-англи, Англи-хасаг толь (= Казахско-английский, Английско-казахский словарь) / ред. Кадер Сайран. Улаанбаатар: Непко паблишинг, 2017. $274 \mathrm{x}$.

Хятад үсгийн толь 2015 - Хятад үсгийн толь (= Словарь китайской письменности) / ред. Лу Шупин. Бээжин: Ном хэвлэлийн олон улсын сан, ХХК-ний хэвлэлийн газар, 2015. $1150 \mathrm{x}$.

Казахстаны хасаг 2018 - Казахстаны хасаг үндэстний хүн амын тоо (= Демографические данные Казахстана) [электронный ресурс] Население Казахстана в 2018 г. Общая численность // URL: https://mip.phb123.com/city/renkou/21279.html (дата обращения: 27.05.2020).

Хасаг үндэстний 2019 - Хасаг үндэстний танилцуулга (= Ознакомительный очерк о казахах) [электронный ресурс] // Энциклопедия Байду. URL: https://mr.baidu.com/ vucklls?f=cp\&u=a183c38037ef93e1 (дата обращения: 27.05.2020).

\section{References}

Altangül B. Kazakh Culture and Traditions. Ulaanbaatar: Soembo Printing, 2017. 108 p. (In Mong.)

He Yanlong (ed.) Kazakh-Chinese Dictionary. Beijing: Beijing Lu Yao Technologists Ltd., 2017. (In Kaz. and Chin.)

Jianshin Yan. Northwest China: History of National Minorities. Beijing: People's Publ. House, 2012. 648 p. (In Mong.)

Kader Sayran (ed.) Kazakh-English and English-Kazakh Dictionary. Ulaanbaatar: Nepko Publ., 2017. 274 p. (In Kaz. and Eng.)

Kazakhstan: Demographic Data. Population of Kazakhstan: 2018. Available at: https://mip. phb123.com/city/renkou/21279.html (accessed: May 27, 2020). (In Chin.)

Külmeskhan Z. (ed.) Mongolian-Kazakh Dictionary. Ölgii: Baspager-Ölgii Ltd., 2015. 891 p. (In Mong. and Kaz.)

Lu Shupin (ed.) Dictionary of Written Chinese. Beezhin: International Publishing Foundation, 2015. 1150 p. (In Chin.)

Önörbayan Ts. (ed.) Spelling Dictionary of the Mongolian Language. Ulaanbaatar: Soembo Printing, 2018. 542 p. (In Mong.)

Pateman. Kazakh Culture and Traditions. People's Publ. House, 2008. 376 p. (In Mong.)

Potanin G. N. Essays on Northwestern Mongolia. Vol. II. Ulaanbaatar: Sudar Örgöö Publ., 2018. 304 p. (In Mong.)

The Kazakhs: a Reference Essay. In: Baidu Encyclopedia. Available at: https://mr.baidu. com/vucklls?f=cp\&u=a183c38037ef93e1 (accessed: May 27, 2020). (In Chin.)

Unabridged Explanatory Dictionary of the Russian Language. Mongolian Academy of Sciences, Institute of Language and Literature. Vol. 3. Ulaanbaatar: Woovoo Tekhnologiyn Ltd., 2016. (In Mong.)

Zolbayar G. (ed.) Kazakhs of Mongolia: Ethnography. Ulaanbaatar: Soembo Printing, 2016. 288 p. (In Mong.) 